\title{
O PULO DO GATO DA INDÚSTRIA DA CULTURA
}

\section{THE “ACE IN THE HOLE” OF THE INDUSTRY OF CULTURE}

\author{
Cristina M. Emboaba da C. J. de Camargo \\ Universidade do Estado de Santa Catarina \\ cristina.emboaba@udesc.br
}

\section{Resumo}

Discussão crítica sobre as manifestações musicais produzidas para o consumo industrializado, destacando suas especificidades e usos, da informalidade espontânea ao controle mercadológico/ideológico da indústria da cultura (ADORNO, 1944) e do entretenimento dirigido, suas consequências e perspectivas na sociedade contemporânea de sensibilidade adestrada e gosto nivelado. Em contrapartida, o universo transgressor da arte e o impacto do ensino da música enquanto linguagem (compreensão da obra e a construção do gosto e do juízo estético) como possibilidades de formação crítica e resistência à essa estrutura de controle e de consumo. canção

Palavras-chave: indústria da cultura; ensino musical; arte; cultura;

\section{Abstract}

Critical discussion on musical expressions produced for industrialized consumption, stretching its specificities and usage, from spontaneous informality to marketing/ideological control of industry of culture (ADORNO, 1944) and from directed entertainment, its consequences and perspectives on the disciplined sensibility and leveled taste contemporary society. On the other hand, the transgressive universe of art and the impact of music as language (comprehension of the work and construction of taste and aesthetical judgement) as possibilities for critical formation and resistance to this structure of control and consumption.

Keywords: industry of culture; musical teaching; art; culture; song. 
A expressão o pulo do gato, usada na fala cotidiana, geralmente refere-se à segredos mirabolantes, estratégias e/ou fatores decisivos que determinaram o sucesso de uma ação, como também pode referir-se a uma manobra espetacular executada para safar-se de uma situação difícil. Nesse sentido, qual foi o pulo do gato da indústria da cultura que the possibilitou tamanha dominação e controle do âmbito cutural nas sociedades contemporâneas principalmente no ocidente?

Os mecanismos de controle e manipulação das massas são inerentes aos processos sociais e das relações humanas e tão antigos quanto o próprio homem, mas o que aconteceu a partir do século XX que propiciou tamanho poder de dominação, ultrapassando fronteiras geográficas, linguísticas e culturais? Em quais dimensões da alma humana essa "invasão" aconteceu? Quais os mecanismos de perpetuação desse sistema? Existem alternativas para driblarmos essa hegemonia cultural e mantermos o pensamento crítico?

Para conduzir essa discussão usaremos o universo da música, e tomaremos como exemplo a canção brasileira (folclórica e popular), que durante o século XX transformou-se em um rendoso produto dessa estrutura ideológica/mercadológica em detrimento de suas singularidades regionais e até do seu aspecto musical enquanto linguagem artística.

\section{Música e canção: confusões epistemológicas}

Até o início do século XX existiam no Brasil vários gêneros populares instrumentais provenientes da diversidade musical do campo (folclórica) e dos centros urbanos, vários deles relacionados à dança, como o maxixe, lundu, chorinho, corta-jaca e o tango brasileiro', estudados desde então por musicólogos, historiadores e escritores como Mario de Andrade, Oneyda Alvarenga, José Ramos Tinhorão, José Miguel Wisnick, Marcos Napolitano, entre outros pesquisadores.

Com o surgimento do rádio e toda estrutura mercadológica criada ao seu redor, alguns desses gêneros vinculados à dança

I $\bigcirc$ tango brasileiro confunde-se com o chorinho, mesmo não recebendo inicialmente esta denominação. 
receberam textos e moldaram-se a uma nova função, agora servindo às palavras, à semantização de sensações, sentimentos e histórias. Perderam gradativamente suas singularidades rítmicas, timbrísticas e melódicas por conta do texto cantado. Assim, a canção tomou em importância o lugar do discurso instrumental. Por sua vez, os gêneros instrumentais tipicamente brasileiros e característicos de algumas regiões rurais el ou urbanas foram reduzidos a um número menor, alguns até caindo no abandono e esquecimento, como o corta-jaca por exemplo. No entanto, o texto cantado possibilitou uma difusão maior desses gêneros instrumentais, tornando-os mais populares e conhecidos.

Esse modelo publicitário que se instalou com a radiodifusão em massa a partir da década de 30 (inicialmente por meio dos rádios clubes brasileiros, mais tarde expandindo-se para uma estrutura de comunicação midiática, televisa e de internet) fez do século XX O Século da Canção ${ }^{2}$ no Brasil, limitando a música de concerto e a música folclórica aos redutos de pesquisa, investigação e invenção. Ocorreu então uma transposição e generalização de conceitos entre esses universos musicais, gerando uma confusão epistemológica em torno do vocábulo música, que passou a ser sinônimo de canção.

Com o uso recorrente e cada vez mais intenso e generalizado nas mídias da palavra música para designar canção, esses vocábulos tornaram-se praticamente sinônimos no decorrer do século XX no Brasil, instalando-se uma confusão epistemológica não só com esses termos, mas também, cancionista/compositor, gênero/ritmo, entre outros, que, com aplicações generalizadas e indiscriminadas, levou-se a compreender erroneamente a parte pelo todo.

A canção é uma expressão artística dual de música e poesia. Durante séculos a música e a poesia desenvolveram-se numa relação estreita de simbiose, e embora extremamente diversas, conseguiram estabelecer afinidades quanto à articulação do som, gerando a música vocal. Enrico Fubini (2003) assim descreve essa relação:

(...) na música vocal, a música gostaria de poder assumir as características significativas da palavra, a precisão em denotar os objetos e sobretudo os sentimentos; e, em contrapartida, a palavra gostaria de poder assumir

2 Título do livro e da pesquisa de Luiz Tatit, 2004. 
a liberdade alusiva da música, o seu lirismo e o seu livre desdobramento na intensidade expressiva da linha melódica (FUBINI, 2003, p. 25).

Ainda para Fubini, existe a possibilidade de um isomorfismo entre a expressão musical e os afetos, que permite à música uma autonomia semântica, estando ou não combinada com a linguagem verbal:

Na linguagem verbal este isomorfismo vem à superfície quando a expressão verbal é exclamada, entoada, gritada, ou seja, quando nela se insinua o elemento musical que a pura expressão verbal não prevê ou que prevê somente como elemento acessório e não essencial. Neste caso, o elemento musical pode não só aumentar consideravelmente a eficácia do discurso verbal, como pode mesmo, às vezes, contradizê-lo ou frustrá-lo. Daqui se pode deduzir que há uma espécie de autonomia semântica da expressão musical que pode assumir a sua coloração emotiva e afetiva, quer quando é combinada com a linguagem verbal, quer quando é isolada como um elemento autônomo e independente (ibidem, p. 32).

No entanto, a autonomia do discurso musical foi diminuindo na medida em que o gesto melódico submeteu-se à palavra cantada. Com a predominância do uso da canção como forte produto da indústria da cultura, a música perdeu sua autonomia enquanto linguagem na cultura midiática e manteve-se atrelada à expressão cancional, ou seja, vinculada e a serviço da linguagem verbal, e o termo música passou a referir-se, quase que exclusivamente, ao termo canção. Dessa forma, para uma grande parte dos brasileiros, música é compreendida meramente enquanto canção. Por estar sempre a serviço da estabilização da compatibilidade entre texto e melodia (TATIT, 2004), a estrutura musical do gênero da canção popular tornou-se cada vez mais simplificada, possibilitando uma ênfase maior à expressão verbal. Um exemplo deste processo é a produção, por exemplo, de gêneros como o funk, rap e hip-hop, nos quais a melodia sofre uma redução em sua amplitude melódica - mais restrita 'a tessitura da fala - resultando numa fala mensurada, ou seja, uma declamação com reiterada repetição sempre nos mesmos padrões e acentos rítmicos e com poucas alturas definidas. Nesses gêneros citados o texto ganha importância maior, pois trata 
de assuntos e temas sociais representativos para importantes parcelas da sociedade (violência social, desigualdade, discriminação, racismo, míseria, entre outros) e a parte musical da canção vem dar o suporte harmônico e rítmico para que o texto cantado seja expressado e compreendido. Essa questão esbarra em algumas polêmicas musicais, estéticas e filosóficas, pois depende do que se entende por Arte e Cultura e o quanto as questões sociais podem/procuram legitimar um gosto musical frente ao juizo estético (PAREYSON, 200l [1984]).

Stravinsky também apontou essa semantização da música intrumental por meio da música vocal:

$\bigcirc$ elemento instrumental dispõe de uma autonomia que o elemento vocal não possui, por estar preso às palavras. [...] A canção, mais ou menos ligada à palavra, acabou por tornar-se uma espécie de complemento, evidenciando assim sua decadência. No momento em que a canção é usada apenas para dar expressão a um discurso, ela deixa $O$ domínio da música, e nada tem a ver com ele (STRAVINSKY, 1994 [ l a ed. 1942], p. 46).

mesmo processo ocorreu com a palavra compositor, que num empréstimo do universo da música de concerto passou a ser utilizada para denominar o cancionista, que é o autor da canção. Uma situação recorrente é quando nos referimos aos cancionistas da música popular urbana como compositores, o que prescindiria de conhecimento de técnicas de composição, teorias de estruturação e de estética, contraponto e harmonia, história da música e principalmenta da própria linguagem musical essencialmente grafocêntrica, num trabalho que envolve um contexto mais denso na composição dos parâmetros musicais (textura, alturas, intensidades, durações, timbres etc.).

Mas um compositor também pode ser um cancionista e usar de tudo isso para escrever uma canção. $\bigcirc$ ponto é que a canção é obra multimidiática fazendo o som dividir espaço com as palavras como citou Stravinsky - sendo distante da música que usa de estimulos sonoros e abstratos para conduzir seu discurso. Vale realçar que a poesia normalmente tende às metáforas para caminhar à abstração de seu discurso, que por natureza é objetivo e descritivo; já a música é abstrata por natureza, conduzindo seu discurso para algo mais concreto, vide títulos de sinfonias do período clássico (que se remetem 
à um objeto ou emoção). A beleza da canção está no diálogo entre esses dois extremos (som e palavra) que se estendem utopicamente para atingir um ao outro.

Grande parte dos cancionistas populares têm uma outra relação com a invenção musical: a de expressão espontânea e intuitiva enquanto manisfestação de seu contexto cultural predominantemente vinculada à mímesis ${ }^{3}$ e uma prática repetitiva, o que não desqualifica a produção cancional brasileira - rica em elementos musicais regionais e folclóricos - mas é um processo de invenção musical diferente ao de um compositor. A perpetuação desses elementos das variadas regiões e folclore brasileiro, diluídos na produção da canção, acaba cumprindo as funções de conservação de tradições (ao reconectar-se com as origens) e a produção de uma sonoridade singular na forma de inventar melodias e de interpretá-las, determinada principalmente pelas especificidades fonéticas do português falado no Brasilt4.

Sobre o uso não diferenciado de conceitos - quando se toma canção por música, cancionista por compositor, ritmo por gênero, etc. lembramos do filósofo italiano Luigi Pareyson quando afirma que "usar uma mesma palavra para significados diversos, quando não inteiramente opostos, é sempre desaconselhável, porque gera uma confusão inútil e prejudicial e, além disso, nada resolve, dado que a tarefa de distinção não só não resulta evitada, mas antes se torna ainda mais urgente e ineludivel" (PAREYSON, 2005 [1971], p. 151).

Toda essa confusão epistemológica gerada pelo uso indiscriminado e indevido na indústria de canções determinou o total desconhecimento da música enquanto área de conhecimento por parte da grande maioria da população brasileira, agravado com a ausência de um ensino de música regular que trabalhasse a linguagem e os

3 Ato repetitivo de regras e padrões do cotidiano visando a perpetuação cultural e de tradições. Encontra-se em oposição dialética à arte, que inventa, renova, transgride a cultura e seus padrões pré-estabelecidos, fundando novos paradigmas.

4 Algumas características dessa vocalidade singular do português falado no Brasil é uma sonoridade com predominância de sons nasais e guturais produzidos com o palato mole relaxado, diferente de outros idiomas onde o palato mole é naturalmente alçado. Essa característica provavelmente é decorrente da acomodação dos fonemas provenientes dos vários idiomas que influenciaram o nosso português, desde o Nhengatu - criado artificialmente pelos jesuítas para possibilitar a comunicação com os indigenas brasileiros no período colonial, e a lingua geral paulista - até os diversos idiomas europeus e orientais que por aqui aportaram desde a invasão das terras brasileiras a partir de 1500 , gerando uma complexidade fonética. 
diversos universos musicais nas escolas.

Esses exemplos de generalizações, que geram confusões quando tomam uma parte pelo todo, também interferiram na espontaneidade e informalidade da invenção musical popular; numa cultura musical cada vez mais impregnada de clichês e estereótipos, a imaginação popular tornou-se contaminada pelos padrões repetidos à exaustão no crescente sistema de comunicação e entretenimento industrializado, impactando a ludicidade e espontaneidade típicas dessas manifestações.

Mas será que toda canção se encontra no âmbito da indústria da cultura? Onde se dá o limite entre a invenção cancional e a produção estandardizada dirigida à massa?

\section{Canções e o consumo industrializado}

A canção folclórica traz em sua essência musical e textual tradições muitas vezes antigas que permaneceram numa coletividade por meio da transmissão anônima e oral e da perpetuação de histórias, jogos e brincadeiras infantis, festas religiosas e comemorações sazionais, entre outras. Geralmente acompanhadas por movimentos ou danças possibilitam uma prática musical aberta a variações e reinvenções, que ao longo do tempo se perpetuam na memória da comunidade de uma forma dinâmica, agregando as transformações decorrentes do tempo. Neste caso, os parâmetros musicais e as formas de expressão são vivenciados a cada jogo/brincadeira ou festa folclórica, mantendo sempre as possibilidades para a práxis e a poética musicais. É uma produção espontânea e coletiva de canções oriundas de uma comunidade, atendendo as particularidades sociais e/ou religiosas de um agrupamento específico de pessoas. Geralmente essas tradições coexistem e sobrevivem à voracidade da indústria, mas podem também ser por ela absorvidas e padronizadas, perdendo então suas trajetórias de transformação, uma vez que alguns parâmetros musicais são fixados por meio de gravações e da repetição empreendida como estratégia de divulgação e de venda, distanciando-se de sua origem.

Segundo Pareyson, quando a arte apresenta um caráter social é chamada de arte popular, e é aquela que: 
[...] canta e figura temas populares, obra coletiva e anônima do próprio povo, mas que agora é interpretada de modo mais conforme a estrutura da própria arte [...]. A arte popular é tal, não porque tenha sido feita pelo povo, mas porque tem o povo como assunto e como ambiente: nascida do povo e para o povo, tem como autor quem soube interpretar a alma popular, recolher temas, realizar suas aspirações, precisar seus gostos. [...] a arte realiza o mais difícil conceito de sociabilidade, porque ela fala a todos, mas a cada um de seu modo, e assim assegura uma universalidade através da individualidade e institui uma comunidade através da singularidade (PAREYSON, 2001 [1984], p. 118, 119 e 123).

A artesania popular perpetua-se em longa tradição, e, para Pareyson, dispõe de um caráter originário e ontológico, pois, diferente da revolução que busca iniciar um novo tempo rompendo com o passado, "a tradição é uma contínua recuperação da origem, [...] àquela origem de onde somente pode derivar uma regeneração do tempo" (idem, 2005 [1971], p. 47 e 49).

Assim, a tradição por meio da mímesis (imitação, representação) proporciona a conservação cultural e a poíesis (invenção) traz a inovação e a originalidade, comparada ao efeito da revolução; ambas deveriam co-existir numa relação dialética de conservação e transformação. No entanto, se essa relação se desfaz e prevalece uma ação destituída de origem ou de inovação, onde "continuar sem inovar significa apenas copiar e repetir, e inovar sem continuar significa fantasiar no vazio, sem fundamento [...], então a forma decai para a fórmula, o modelo para o módulo, o estilo para cunho, a obra para estereótipo e não aparece senão a inerte repetição, a estéril reprodução do imitador rasteiro" (idem, 2001 [1984], p. 137-138).

Já a canção popular, rural ou urbana, de autoria determinada, nascida como expressão espontânea de uma pessoa ou grupo, quando inserida num contexto comunitário mantém as mesmas possibilidades de reinvenção e performance da canção folclórica. No entanto, quando é absorvida pela indústria e passa por todo um processo de pasteurização, estandardização e adequação aos padrões midáticos, sofrendo a repetição necessária para sua aceitação, tende à fixar-se por meio da performance gravada - cujo alicerce é o fonograma - 
transformando-se também em padrão e perdendo o contato com sua raiz originária, que regenera e atualiza a tradição no tempo. Esse tipo de produção de canções é alvo constante da indústria, pois fornece o material cancional que é modificado pela indústria e redirecionado para o público consumidor.

Para Pareyson (2001), a música produzida para o povo ${ }^{5}$ é imbuída de elementos que o representa e com ele se identifica, pois surge como expressão espontânea do povo e a ele se destina. A nosso ver, essa relação funcionou até a comunicação midiática assumir o controle da produção e veiculação musical, alterando profundamente essas relações entre tradições-cancionistas-comunidades. A música passa então a ser direcionada para o consumo povo, com frágeis elementos culturais que o identifica.

Finalmente, a canção popular de massa nascida dentro da fórmula-padrão da indústria da cultura, já pré-determinada à venda e consumo do sempre-igual, é elaborada e direcionada para determinado público alvo, visando atender às preferências convencionadas pela indústria do consumo como qualquer outro tipo de produto comercial (carro, roupa, shampoo, sabão em pó, etc.). A segmentação do mercado musical com a formação de grupos pré-estabelecidos - público infantil, adolescente, universitário, e as classes sociais padronizadas com suas cores A, B, C e D, etc. - direciona e determina a produção de canções a fim de controlar a manutenção dos padrões para o consumo. Assim, atualmente a canção de consumo dita "popular" não parece ser oriunda do povo, mas sim, para o consumo das massas, kitschificadd e sem vinculação com as tradições originais que formaram o público ao qual são destinadas. Nesse contexto, a informalidade e espontaneidade são substituidas pela repetição de fórmulas cancionais bem aceitas, sempre por pouco tempo, sendo logo substituídas por outras que em nada renovam ou que remontam às origens das tradições de comunidades regionais que constituem uma sociedade.

Sobre essa manipulação da canção promovida pela indústria da cultura e a banalização da música nos meios de comunicação (presente em quase todos os lugares enquanto "música ambiente" no contexto do

5 Povo no sentido da doxia, do senso comum.

6 Termo utilizado pelo filósofo Umberto Eco para designar o processo de kitschificação, ou seja, o uso do efeito da obra de arte na produção de bens culturais de consumo padronizados. Ex: Sinfonia de Mozart com bateira, cortina com estampas da Monalisa, etc. 
consumo), Stravinsky ressalta que "espalhando-a em todas as direções sem tomar certas precauções, oferecendo-a displicentemente a um público que não está preparado para isto, deixa-se esse público exposto a uma saturação mortal" (STRAVINSKY, 1994 [ l a ed. 1942], p. 121).

A saturação do gênero canção popular urbana levou à uma estandardização e mudanças nos hábitos de audição, pois, dispensando o ouvinte do esforço de "seguir o fluxo musical concreto, como the dá, de fato, modelos sob os quais qualquer coisa concreta ainda remanescente pode ser subsumida" (ADORNO, 1941, p. 121), despojou a espontaneidade e a informalidade, desnecessárias numa escuta pré-digerida, e promoveu reflexos condicionados, principalmente aqueles ligados aos aspectos do ritmo e do movimento, responsáveis diretos pela estimulação catártica (kathársis ${ }^{7}$ ) do entretenimento, além de produzir um gosto nivelador (idem, 2011 [ l a ed. 1973], p. 52) na sociedade de massa. Nesse sentido, a imitação foi o fio condutor dessa estandardização e a competição foi o seu processo, culminando na cristalização dos padrões, sendo excluído tudo que diferisse deles. "Entender música popular significa obedecer a tais comandos ao escutar. A música popular impõe os seus próprios hábitos de audição" (idem, 1941, p. 124). Adorno (1941) aborda o processo de plugging [literalmente, arrolhamento ou, como se diz vulgarmente, enfiar guela abaixo - (ADORNO, 1941)] como "uma continuação do processo inerente à composição e ao arranjo do material musical. A promoção pelo plugging almeja quebrar a resistência ao musicalmente sempreigual ou idêntico, fechando, por assim dizer, as vias de fuga ao sempreigual" (ibidem, p. 125).

A utilização do processo de repetição promocional da canção, o plugging, leva à institucionalização e estandardização dos hábitos de audição, conferindo à canção uma relevância psicológica que de outro modo não teria. Assim, a promoção é o inevitável complemento da estandardização.

Nesse contexto, a canção popular urbana é utilizada no modelo publicitário acima descrito como estrutura de distração e de desatenção e está ligada ao modo de produção e de mecanização

7 "A Kathársis é um efeito da mimésis sobre o receptor, o qual fecha o cicuito dos diferentes, mas coexistentes, objectos da representação. Este efeito, que resulta de uma série de transferências psicanalíticas para o receptor, completa a relação entre realidade e arte" (MIRA, 2012, p. 8). 
do trabalho (tal como a Verfremdung em Marx que sugere a alienação do trabalho, quando o pensar e o agir se tornam atividades distintas, ou mesmo a Verfremdung em Heidegger, uma alienação enquanto esquecimento do ser). Surge então o correlato não-produtivo dessa estrutura de produção: o entretenimento industrializado, controlado, dirigido. Realizado como forma de relaxamento sem envolver nenhum esforço de atenção e concentração, esse novo tipo de entretenimento envolve os sentidos num gozo de sensações que busca o próprio prazer e a simulação de emoções, provavelmente inexistentes ou imperceptiveis no massificado cotidiano da vida urbana atual.

Anteriormente à indústria da cultura, o entretenimento era associado às ideias de jogo ${ }^{8}$, brinquedo, diversão, desafio, ou seja, à atividade lúdica. $\bigcirc$ filósofo Herbert Marcuse (2013) vai mais longe quando aborda o entretenimento ligado originariamente à ideia do Eros - princípio da vida e do prazer - que trava uma constante luta com Thanatos - o princípio da morte e da realidade -, ou seja, a ideia do prazer, da diversão, da gratificação do jogo contrapondose à ideia do esforço laborioso do trabalho e seu caráter repressivo, (autossublimação do prazer em submissão à racionalização). Nessa trajetória de especulação, a partir do pensamento freudiano em relação ao desenvolvimento civilizatório da humanidade, Marcuse resgata a ideia da perversão do Eros, que converteu-se apenas na ideia de sexualidade por conta da repressão dos instintos, e emprega-o no que, a seu ver, ocorreu com a atividade lúdica: a perversão da ideia de entretenimento, que transformou-se em uma atividade destituída de ludicidade e desafio, passando a ter um prazer mensurado, prédirigido e controlado industrialmente. Cores exuberantes e fortes, sons cada vez mais ensurdecedores, paladares picantes, situações limites que geram emoções fortes, são exemplos cada vez mais comuns nessa lucrativa área que produz um relaxamento padronizado e pré-digerido, promovendo a escapada da monotonia que se instalou no âmbito do trabalho, principalmente aqueles ligados à mecanização e à repetição de atividade.

Com o declínio da consciência, com o controle da informação, com a absorção do indivíduo nacomunicação em massa, o conhecimento é administrado e condicionado. $\bigcirc$ indivíduo não sabe realmente o que se passa; a máquina esmagadora de educação e entretenimento une-o a todos

$8 \bigcirc$ jogo tem como único propósito a "gratificação dos instintos" e com fim em si mesmo (LANTOS, 1943, p. 117 apud MARCUSE, 2013, p. 164). 
os outros indivíduos, num estado de anestesia do qual todas as ideias nocivas tendem a ser excluidas. E, como o conhecimento da verdade completa dificilmente conduz à felicidade, essa anestesia geral torna os indivíduos felizes. Se a ansiedade é mais do que um mal-estar geral, se é uma condição, um estado existencial, então esta chamada "idade de angústia" distingui-se pelo grau em que a ansiedade desapareceu de qualquer forma de expressão (MARCUSE, 2013, p. 81).

ambiente lúdico é um mundo ficcional paralelo ao mundo real que une pessoas que se submetem por vontade própria às regras estabelecidas. Nesse artigo apontamos a possibilidade do ambiente lúdico também ter-se padronizado pela industrialização excessiva, escravizando o indivíduo em todo seu cotidiano.

Na sociedade do séc. XXI algumas características comportamentais como a angústia, o medo, a instabilidade e a insegurança promoveram, principalmente na parcela jovem, uma busca desenfreada por mecanismos de entretenimento industrializado que lhes garanta um alívio imediato e momentâneo de suas incertezas (Ex: seriados -TV e internet-, sagas cinematográficas com requintes de produção tecnológica, jogos e aplicativos nos celulares, só para citar alguns "passatempos"). No lugar de um filme com duração de duas ou três horas temos à disposição seriados na internet com várias temporadas e que promovem uma imersão duradoura no mundo ficcional de uma série. Esses sentimentos, como a angústia e o medo, estiveram sempre presentes nas sociedades dos vários períodos históricos, o que mudou foi a forma de enfrentá-los (ou não!). A busca pelo controle e dominação atualmente conta com requintes tecnológicos que manipulam a consciência dos indivíduos, mantendo-os num estado de anestesia, alienação e pseudo liberdade.

A canção, e em especial a popular urbana, assim como boa parte da produção cinematográfica e televisa tornaram-se bens culturais de consumo amplamente oferecidos por essa indústria da cultura e do entretenimento no transcorrer do século XX, apoiadas em uma mega estrutura promocional e de eventos que fabrica artificialmente os hits e os artistas que farão sucesso (sempre por um período temporário). Grande parte da sociedade possue sua trilha musical particular (conectada e 
disponível todo o tempo), contando com ajuda de dispositivos móveis9 cada vez mais numerosos e atrativos facilmente acessiveis a pessoas de diversas idades e condições econômicas (celulares, tablets, iPod, iPad, etc., todos conectados à internet), tornando-se assim consumidora passiva e obediente, ávida pela próxima novidade, distanciando-se da ideia (utópica) de uma sociedade que escolhe, trabalha e determina seu caminho histórico - utopia perseguida por muitas gerações. 0 filósofo francês Gilles Lipovetsky (2005) denominou esse comportamento de pode tudismo, surgido em nossa contemporaneidade como processo de personalização.

Sob a égide do consumo de massa e sua uniformização de comportamento, Lipovetsky destaca a face suplementar $e$ inversa desse fenômeno de massa: "a acentuação das singularidades, a personalização sem precendentes dos indivíduos" (LIPOVETSKY, 2005, p. 86), ou seja, os produtos industriais passam a ser customizados pelo consumidor, tornando-os objetos particulares e singulares. Em resposta e reação ao processo de padronização e estandardização inerentes à indústria da cultura, ocorre o processo de personalização - ou deveríamos chamar de (pseudo) personalização: "Liquefação da identidade rígida do Eu e suspensão da primazia do olhar do Outro - em todos os casos - narcisismo funciona como agente do processo de personalização" (ibidem, p. 39) - basta lembrarmos das incontáveis auto-fotos (selfie) divulgadas a todo instante nas redes sociais.

$\bigcirc$ processo de personalização anexou a própria norma, assim como anexou a produção, o consumismo, a educação e a informação. A norma dirigista ou autoritária foi substituida pela norma 'indicativa', suave, pelos 'conselhos práticos', as terapias 'sob medida', as campanhas de informação e sensibilização por meio de filmes humorísticos e publicidades repletas de sorriso (ibidem, p. 44).

Uma vez isolados, os indivíduos enfraquecem seus vínculos sociais por estarem mergulhados num confortável ambiente hedonista, sempre

9 Sobre a frenética produção de numerosos e sofisticados dispositivos móveis, cada vez mais acessiveis a grande parte da população, Lipovetsky considera que "a dissipação dos grandes códigos estéticos, os extremismos das vanguardas transformaram de alto a baixo a percepção das obras, as quais se tornaram equivalentes a absurdos gadgets de luxo" (LIPOVETSKY, 2005, p. 137). 
buscando uma satisfação narcisista, ambos decorrentes dessa estrutura de consumo cada vez mais individualizante. Perde-se a força social e cultural geradoras das tradições singulares das comunidades, que se perpetuavam e se renovam espontaneamente através do tempo.

Nesse contexto da industrialização da cultura, as dimensões estruturais da música sofreram profundas alterações com a estandardização para o consumo de massa, promovendo uma redução dos parâmetros básicos que a compõem (altura, duração, intensidade e timbre), bem como dos atributos de expressão (andamento, dinâmica e articulação) e nos princípios da poética musical (repetição, contraste e variação). No padrão da canção de consumo os parâmetros, os atributos e os princípios musicais foram reduzidos: o que se percebe é um ostinato rítmico em primeiro plano, que sofre mínimas ou imperceptíveis alterações de timbre, articulação e andamento durante a execução da canção, um acompanhamento harmônico (normalmente em movimento paralelo) realizado sempre pelo mesmo grupo instrumental (guitarra, baixo, bateria e teclados) e uma melodia de pequena tessitura localizada na região média da voz do intérprete, bem próxima à região de fala. A riqueza de timbres, rítmos, instrumentos e gestos melódicos singulares que constituiam as tradições musicais das diversas regiões brasileiras que muito influenciaram a música autoral popular e de compositores brasileiros (Villa Lobos, Camargo Guarnieri, Guerra Peixe, Osvaldo Lacerda, Mignone, Vilani-Cortes, Itiberê, entre tantos outros) perderam espaço para uma redutiva instrumentação (teclados, guitarra, baixo elétrico e bateria), bem como uma sensivel redução dos gêneros, ritmos e modos melódicos utilizados.

A forma de percebê-los também se alterou, uma vez que a escuta musical tornou-se cada vez mais individualizada por meio dos já citados dispositivos sonoros e seus potentes fones de ouvido, que distanciam o ouvinte do som enquanto um fenômeno acústico. $\bigcirc$ som gravado acusticamente sofre interferência e transformação já em sua captação, bem como nas fases de mixagem e edição, retirando ou adicionando frequências e características timbrísticas, simulando ambientes acústicos diferentes da nossa percepção natural. Vale ressaltar que as pessoas perderam a noção da dificuldade de se criar um som no instrumento acústico.

EXEMPLO: Uma criança pega uma guitarra com distorção e com um toque gera um som forte em volume; essa mesma criança, se tocar 
num violão conseguirá emitir um volume muito fraco. Uma analogia a essa situação é o uso da espada e da arma de fogo: dominar a técnica do corte da espada para gerar um estrago necessita de anos de treinamento e condicionamento, já a arma de fogo basta apenas apertar o gatilho.

Lipovetsky compreende essa situação como uma "geração de surdos" que se intimida diante do mundo real, e comenta:

Circulação, informação, iluminação trabalham para um mesmo enfraquecimento do real, o que, por sua vez, reforça o investimento narcisístico: uma vez o real tornando-se inabitável, resta o dobrar-se para dentro de si mesmo, o refugiar-se na autarquia, que a nova voga dos decibéis, dos fones de ouvido e dos concertos pop tão bem ilustra. Neutralizar o mundo pelo poder sonoro, fechar-se em si mesmo, flutuar e sentir no corpo o ritmo dos amplificadores. Hoje em dia o barulho e vozes da vida se tornaram parasitas, é preciso identificar-se com a música e esquecer a exterioridade do real (idem, p. 55).

Essa alienação gerada pelo auto-isolamento social é uma das graves consequências da manipulação e adestramento dos sentidos, que percebem apenas as distorções amplificadas do mundo real, tais como o medo, a violência e a exuberância do poder e do prazer inesgotável de quem o possui.

\section{Entre padrões e singularidades}

No Brasil encontramos em cada região comunidades com características singulares, mas que embaladas pelos mesmos meios de comunicação (acessiveis em quase todo território nacional) tem suas tradições fortemente influenciadas por padrões desligados de qualquer origem próxima e que também não promovem nenhuma renovação, pois partem de uma estrutura que visa apenas a manutenção do status de consumidor adestrado dos bens culturais do sempre igual. Independente da condição social e econômica, as classes sociais brasileiras apresentam um certo nível de adestramento em relação à 
necessidade de consumo dos bens culturais industrializados; as parcelas mais favorecidas economicamente, distantes de suas origens e próximos de tendências globalizantes (na maioria das vezes estadunidenses), acabam por constituir uma camada social midiaticamente guiada por gostos culturais mais próximos aos das regiões do Texas e Miami (USA) do que Amazonas, Pernambuco, Santa Catarina ou Minas Gerais.

Para Marcuse (2013, p. 12), "o povo, eficientemente manipulado e organizado, é livre; a ignorância e a impotência, a heteronomia introjetada, é o preço de sua liberdade".

A padronização do gosto tornou-se a regra, a negação do padrão é a exceção, e como tal precisa ser evitada pela indústria do relaxamento e prazer. No entanto, a sociedade é plural e nessas diversas camadas sociais encontram-se as exceções: pessoas que contrariam as tendências de seus contextos culturais, e são justamente essas que, por vezes, incentivam, e até mesmo promovem as pequenas transformações do âmbito cultural.

Oposta à esta situação provocada pela indústria da cultura onde o momento do reconhecimento é o da fruição sensorial sem esforço, sem questionamento e sem liberdade de escolha (uma vez que a escolha já foi feita através do adestramento da sensibilidade promovida por essa mesma indústria) - encontra-se o universo provocativo e transgressor da arte, que para ser apreciada necessita da concentração e do esforço consciente da percepção, reconhecimento, identificação, análise, interpretação e compreensão, enfim, de um pensar crítico. Não é difícil concluir por que a arte e todas as atividades que envolvem o desenvolvimento da vontade e do pensar - o controle de sensações e emoções, as atividades de dialética e de análise - são suprimidas do nosso cotidiano contemporâneo (escola, trabalho, centros comerciais, programas radiofônicos e televisivos que visam somente a diversão e a venda, etc). A informalidade e a espontaneidade musical ainda vivem, de forma tênue e discreta, à margem dessa estrutura mercadológica e ideológica, numa luta constante de insana resistência.

Despertar essa postura crítica nas pessoas é fundamental para interferir nesta estrutura de controle e alienação por meio da autosedução dos sentidos. É uma estrutura totalitária e ideológica-pois serve às estruturas de exploração e repressão - que pode ser desvendada a partir de ações críticas no espaço educativo e formador das famílias à 
escola, gerando novas possibilidades de resistência e de convívio-nãodirigido, na tentativa sempre de desenvolver a sensibilidade de forma espontânea, ampla e abrangente.

Partindo da construção de bons hábitos da audição, cuidando da percepção sensorial, principalmente a auditiva, e preservando o silêncio, a concentração e o entretenimento (agora enquanto atividade lúdica espontânea, não pré-dirigido e nem industrializado), a educação musical nas escolas, o ensino formal de música, o educador e a estrutura familiar podem contribuir para a diversificação do gosto musical dos jovens em formção (crianças, adolescentes), bem como dos adultos em geral, permitindo-lhes a escolha segundo os critérios por eles vivenciados e aprendidos, num processo vivo, dinâmico e mutável de análise e interpretação, desenvolvendo o juízo estético.

Outra postura fundamental para a resistência aos atuais paradigmas de padronização e alienação é a compreensão da música enquanto linguagem (caráter teórico e estético), utilizando seu caráter inventivo e poético para desenvolver o pensamento crítico por meio da especulação, do questionamento e da invenção. A apreciação e compreensão de obras de arte musicais constroem o referencial estético para o desenvolvimento desse pensamento crítico em música.

A prática musical, por sua vez, por meio do fazer e da repetição para alcançar melhorias na execução (repetição não idêntica de um mesmo trecho musical ora focando a expressão, ora a articulação, ou mesmo a correção de alguns parâmetros para o seu aperfeiçoamento performático) contribui no fortalecimento da vontade e da coragem, características importantes para a atividade artística. É no âmbito da compreensão, e não da pré-compreensãolo, que se pode libertar e

10 Conceito trabalho pelo filósofo Martin Heidegger no livro Ser e Tempo, a estrutura de pré-compreensão (Vorverständnis) pode ser ententida como uma posição prévia, visão prévia e concepção prévia formadas pela nossa historicidade e tradição cultural, num processo complexo que envolve a interpretação e formação de (pre)conceitos sobre as coisas e o mundo. Essa concepção prévia situa-se num momento anterior ao ato de compreender e também precisa ser compreendida. Esse processo da pré-compreensão/ interpretação/compreensão descrito por Heidegger põe-se em movimento com o ato de interpretar, que por sua vez sempre se funda numa posição prévia: "o compreender guarda em si a possibilidade de interpretação, isto é, de uma apropriação do que se compreende", e que determinam nossas escolhas e comunicação, como a fala e a escuta que "fundam-se no compreender. [...] Somente quem já compreendeu é que poderá escutar" (HEIDEGGER, 2011 [ l a ed. 1927], p. 223 e 227). 
distanciar da influência determinante dos padrões culturais, formadores da concepção prévia advinda da historia individual de cada pessoa, ou seja, superar os pré-conceitos, pré-juízos e pré-condições, enraizados durante a vida, na medida em que os compreenda de forma aberta e hermenêutica, e assim aproximar de novas possibilidades de escolhas. $\bigcirc$ processo da compreensão parte sempre da pré-compreensão das coisas, para então permitir, objetivamente, um estado de emancipação das ideias.

Podemos citar alguns projetos de formação musical que fundamentaram sua proposta pedagógica a partir das ideias acima discutidas, com as atividades musicais primordiais (poética, práxis e teoria) permeando o currículo e o ensino da música enquanto linguagem: Música Criança (FFCLRP-USP - idealizado pelo Prof. Dr. Rubens Ricciardi), Tocando a Vida do Instituto Aparecido Savegnago (Sertãozinho - SP - coordenação de Lucas Galon)'", ALMA - Academia Livre de Música e Artes de Ribeirão Preto (coordenação de Lucas Galon), os quais vêm impactando o ensino de música regionalmente também em termos artísticos e sociais, trabalhando na maioria dos casos com crianças e adolescentes advindos de camadas sociais de baixa renda, alguns em situação de risco.

Os processos de compreensão e de emancipação crítica dos padrões são condições primordiais para a invenção poética na arte e para o questionamento na filosofia, cabendo a elas a função libertadora do pensamento, transgressora, provocativa e geradora de dúvidas. No entanto, mesmo a arte sofreu grande interferência desses processos de reprodução e massificação, como aponta Walter Benjamin (1993 [1935]) quando trata da reprodutibilidade técnica da obra de arte.

A repetição e a padronização, inerentes no processo do alto desempenho que a reprodutibilidade técnica atingiu durante 0 século XX, modificaram e interferiram em várias áreas do conhecimento humano, como a arte, por exemplo, que para Benjamin é um "processo novo" (BENJAMIN, 1993 [1935], p. 166) que se desenvolve de forma intermitente e com intensidade crescente na história da humanidade,

II Sobre o projeto Tocando a Vida do Instituto Aparecido Savegnago ver a tese de doutorado $O$ ensino musical na perspectiva da poética, da praxis e da teoria processos de formação alternativos a indústria da cultura de Cristina M.E. C.J. Camargo, p. 138 a 170. 
transformando vários elementos ligados à arte, como a sua significação social, a recepção e percepção artística e a autenticidade da obra. Essa última passou a ter, a partir da reprodutibilidade técnica, uma "existência serial" (ibidem, p. 168), fazendo com que a obra de arte perdesse a sua aura de singularidade, durabilidade e unicidade, mas em contrapartida gerou maior acessibilidade à obra de arte, ou o efeito dela à massa.

Essa massificação, possivel por meio dos processos técnicos de repetição e de padronização de parâmetros e elementos, gerou uma simplificação do objeto (re)produzido, seja ele artístico ou não, a ponto da obra "ser criada para ser reproduzida" (ibidem, p. 171), emancipando-a da função ritualística e de devoção, e transportando-a para a esfera do entretenimento distraido e acrítico, modificando a relação da massa com a arte e atingindo a concepção poética da obra graças ao aperfeiçoamento dessas técnicas (no sentido de meios) de reprodução, como afirma Benjamin :

A arte contemporânea será tanto mais eficaz quanto mais se orientar em função da reprodutibilidade e, portanto, quanto menos colocar em seu centro a obra original [...] Quanto mais se reduz a significação social de uma arte, maior fica a distância, no público, entre a atitude de fruição e a atitude crítica, [...]. Desfruta-se o que é convencional, sem criticá-lo; critica-se o que é novo, sem desfrutá-lo (ibidem, p. 180, 187 e 188).

As manifestações poéticas, das mais diversas origens e características, são rapidamente absorvidas por essa indústria da cultura, por ela pasteurizadas, assimiladas e devolvidas como produto de consumo e entretenimento para a massa consumidora, demonstrando um espetacular poder de controle e manipulação. Nada escapa a essa voraz indústria, e até mesmo as manifestações mais resistentes e contrárias são por ela utilizadas e absorvidas, dispersando e dissipando a iniciativa de resistência, com ironia e humor, ao incorporá-la ao status quo do consumo do entretenimento e do padrão.

Esta confusão gerada pela indústria da cultura coloca no mesmo caldeirão bens culturais criados com o intuito da eficácia da venda, como vários segmentos da canção de consumo, canção popular urbana e obras de arte que são frutos de uma artesania, de singularidade 
poética e visão de mundo. Estabeleceu-se uma mímesis esvaziada de poíesis (invenção) construida a partir da aliança do capital com a indústria, com a ciência e a tecnologia, com padrões pré-estabelecidos e em sua maioria redutivos, que acabam por coibir qualquer modificação no status quo do consumo. Quando a indústria da cultura deslocou o poder político para a economia e a cultura passou a ser um bem capital produzido por essa indústria, adveio daí a massificação de produtos de consumo, que com o incremento da tecnologia tornou os bens culturais esvaziados de poíesis (invenção, poética), concebidos apenas pela imitação e reprodução de estereótipos. Estabeleceu-se uma nova relação: a mímesis da mímesis - repetição da repetição - distanciada da invenção ou de qualquer poética que pudesse transgredir e alterar o padrão do sempre igual.

Esta indústria do entretenimento e do consumo alcançou sem muita resistência os seus objetivos no Brasil, invadindo e contaminando vários setores da sociedade, principalmente a educação, que por essência é mimética - realiza-se no âmbito da cultura - reduzindo-a a um adestramento técnico. Essa educação adestradora está inserida na crescente proletarização/tecnicização e na massificação da sociedade e é parte desse processo de auto-alienação da massa.

Já a poíesis, com suas singularidades e excessões, perigosamente questiona, transforma, altera, transgride, gerando um desequilibrio quando desenvolve um pensamento dialético e articulado com os fundamentos da poética, práxis e teoria, que rompe as fronteiras da música e da arte e provoca no indivíduo uma mudança no seu modo de ver, analisar e interagir com as coisas e o mundo. Desperta-se então no indivíduo um pensamento emancipado dos padrões impostos pela indústria da cultura, impedindo-o de tornar-se refém da manipulação inerente ao consumo mercadológico, e que começa de fato a exercer seu poder de escolha.

Essa discussão faz parte de um Zeitgeist (espírito do tempo) próprio de nossa época, que contempla sociedades complexas, com necessidades diversas e singulares, mas que se encontram culturalmente estandardizadas e massificadas, inseridas no paradigma de consumo dos bens culturais e industriais, já pré-digeridos, perpetuando a sobrevivência do atual sistema econômico.

Nesse sentido, uma educação fragmentada e adestradora facilita e colabora com a perpetuação desse status quo. Essa estrutura de consumo cultural contaminou também o ensino da música 
no Brasil, que, salvo em raras instituições educacionais e musicais, sofre profundandamente a hegemonia dos paradigmas da indústria da canção como modelo para a formação musical, determinando um distanciamento do conhecimento até hoje produzido.

A dominação do âmbito cultural - aqui entendido como os padrões, regras, hábitos e tradições que regem o cotidiano - foi o pulo do gato da indústria da cultura para a colonização da alma dos

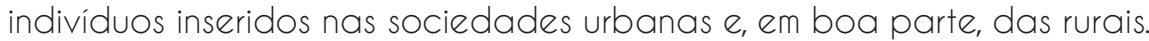
Uma vez controlada a construção e a formação da sensibilidadel percepção (gosto e juízo estético) com a padronização dos bens culturais (dos itens necessários aos mais supérfluos), o processo de subjugação do homem tornou-se cada vez mais eficaz, produzindo a sensação de uma (pseudo) liberdade de escolha dentre as incontáveis possibilidades de bens de consumo, ironicamente num momento em que as "realizações materiais e intelectuais da humanidade parece permitir a criação de um mundo verdadeiramente livre" (MARCUSE, 2013, p. 20). Apoderando-se do universo da cultura, a indústria promoveu o adestramento dos sentidos através da colonização, padronização e nivelamento do gosto pessoal; interferiu na formação do juízo estético ao generalizar e confundir epistemológicamente teorias, universos e conceitos, transformando alguns elementos de uma determinada cultura em produtos de consumo massificado para todo o mundo.

Assim, graças à estrutura mercadológica constituída desde o início do século XX, proveniente do sistema capitalista e a que denominamos indústria da cultura, a música hoje, em sua grande maioria, não é necessariamente fruto de uma artesania popular, espontânea e lúdica, representante de tradições e características singulares de comunidades regionais, mas sim, é uma produção cancional direcionada para um consumo industrializado.

No entanto, excessões acontecem e a força do Eros - explosão libidinosa e instintiva da invenção e imaginação - pode escapar das estruturas de controle/exploração/repressão e, de alguma forma, revitalizar o cancioneiro folclórico e o popular autoral, subvertendo a ordem do controle e do consumo dirigido; ou então, uma explosão estésica ${ }^{12}$ e estética pode ocorrer através do universo transgressor da Arte, inaugurando novos paradigmas e fundando nova história. Mesmo que raras, são as excessões e suas singularidades que iniciam o caos das transformações.

12 Relacionada a estesia, sensibilidade, percepção sensorial. 


\section{Referências}

ADORNO, Theodor Wiesengrund; HORKHEIMER, Max. Dialética do Esclarecimento: fragmentos filosóficos. Trad. Guido Antonio de Almeida. Rio de Janeiro: Jorge Zahar Editora, 1985 [ l a ed. 1944].

ADORNO, T. U. \& SIMPSON, G. On popular music. In: HORKHEIMER, Max, ed. Studies in philosophy and social science. Trad. Flávio R. Kothe. Nova York: Institute os Social Research, 194 I [194 I], v. IX, p. 17-48.

ADORNO, Theodor Wiesengrund. Educação e Emancipação. Trad. Wolfgang Leo Maar. Rio de Janeiro: Paz e Terra, 1995 [ l a ed. 1971 ].

ANDRADE, Mário de. Ensaio sobre a música brasileira (publicado em 1928). 3a ed. São Paulo: Vila Rica; Brasilia: INL, 1972.

BENJAMIN, Walter. Magia e Técnica, Arte e Politica. Trad. Sergio Paulo Rouanet. São Paulo: Ed. Brasiliense, 1993 [ 1935 ].

CAMARCO, Cristina M. Emboaba da C. J. de. O ensino musical na perspectiva da poética, da práxis e da teoria - processos de formação alternativos à indústria da cultura. São Paulo, 2014, 214 f. Tese de doutorado: PPCMUS ECA USP.

FUBINI, Enrico. Estética da Música. Lisboa: Edições 70, 2012.

HEIDECCER, Martin. A origem da obra de arte. Trad. Maria da Conceição Costa. Lisboa, Portugal: Edições 70, 2005 [ 1935/36, la ed. 1977].

Ser e Tempo. Trad. Marcia Sá Cavalcante Schuback. Petrópolis, RJ: Vozes; Bragança Paulista, SP: Editora Universitária São Francisco, 2011 [ la ed. 1927].

LIPOVETSKY, G. A era do vazio: ensaios sobre o individualismo contemporâneo. Trad. Therezinha Monteiro Deutsch. la ed. brasileira; Barver, SP: Manole, 2005.

MARCUSE, Herbert. Eros e Civilização: uma interpretação filosófica do pensamento de Freud. Trad. Álvaro Cabral. 8a. ed. Rio de Janeiro: ITC, 2013. 
MIRA, David Moedas. As sombras de Platão ao Realismo de Iracema: a representação do Real no Cinema. Dissertação de Mestrado [6 lp.] Lisboa: Universidade Nova de Lisboa - Faculdade de Ciências sociais e humanas, 2012.

NAPOLITANO, Marcos. História e Música. História cultural da música popular. Belo Horizonte: Ed. Autêntica, 2002.

PAREYSON, Luigi. Estética: teoria da formatividade. Trad. Ephraim Ferreira Alves. Petrópolis, RJ: Vozes, 1993 [ 1954].

Verdade e Interpretação. Trad. Maria Helena Nery Carcez, Sandra Neves Abdo. la ed. - São Paulo: Martins Fontes, 2005 [1971].

Os problemas da estética. Trad. Maria Helena Nery Garcez. 3a ed. - São Paulo: Martins Fontes, 2001 [ 1984].

STRAVINSKY, Igor. Poética Musical em 6 lições. Trad. Luiz Paulo Horta. - Rio de Janeiro: Jorge Zahar Editor, 1996 [ l a ed. 1942].

TATIT, Luiz. O Século da Canção. Cotia - SP: Ateliê, 2004.

TINHORÃO, José Ramos. Pequena História da Música Popular. 6a. ed. São Paulo: Art Editora, 1991.

SãoPaulo: Ática, 1981.

Música popular: do gramofone ao rádio e TV.

UISNIK, José Miguel. Machado, Maxixe. Teresa - Revista de Literatura Brasileira, n. 4/5. São Paulo: 2004.

\section{Sobre a autora}

Doutora em musicologia pela PPCMus ECA/USP, é docente efetiva do Departamento de Música da UDESC (SC), responsável pela área de Regência Coral, Coral e prática de conjunto.

Recebido em 24/04/2017

Aprovado em 21/09/2017 